永文・水資源学 会誌

J. Japan Soc. Hydrol. \& Water Resour.

Vol. 9. No. 4 (1996) $\quad$ pp. $351-357$

\title{
落葉広葉樹二次林における蒸発散量の季節変化
}

\section{Seasonal course of evapotranspiration in a deciduous broad-leaved secondary forest}

\author{
玉井幸治* \\ (森林総合研究所関西支所) \\ Koji TAMAI \\ Kansai Research Center, Forestry and Forest Products Research Institute \\ 服部重昭** \\ (名古屋大学農学部) \\ Sigeaki HATTORI \\ Faculty of Agriculture, Nagoya University \\ 後藤義明* \\ (森林総合研究所関西支所) \\ Yosiaki GOTO \\ Kansai Research Center, Forestry and Forest Products Research Institute
}

\begin{abstract}
The evapotranspiration rate was calculated by Thornthwaite-Holzman model from the data obtained in a deciduous broad -leaved secondary forest in Yamashiro Town, Sohraku Country, Kyoto Prefecture. The parameters showing the effectiveness of sensible heat exchange in this model were estimated to be 0.12 in a foriaged season and 0.077 in a defoliated season, i.e. the former is 1.5 times as high as the latter. The maximum daily rate of evapotranspiration was stable and estimated to be about $12 \mathrm{MJ} /\left(\mathrm{m}^{2} \cdot\right.$ day $)$ in a foliaged season. On the other hand, those calculated in a defoliated season varied widely from about $2 \mathrm{MJ} /\left(\mathrm{m}^{2} \cdot\right.$ day) in January to $6-7 \mathrm{MJ} /\left(\mathrm{m}^{2} \cdot\right.$ day) in November and April.

In comparison of the result calculated by Thornthwaite-Holzman model with that introduced by Bowen ratio method, it was revealed that Thornthwaite-Holzman model is able to estimate more accurately in a defoliated season, and give no less accurate estimate in a foliaged season than Bowen ratio method does.

The ratios of evapotranspiration against effective radiation were estimated to be about $40 \%$ from January to April and about $60 \%$ from June to November. The increase of this ratio delayed about one month from a leafing time. Moreover, these ratios were almost equal to those in a Japanese Hinoki forest and a Swedish pine forest, although there were differences in a seasonal variations.
\end{abstract}

Key words : Thornthwaite-Holzman model, Water balance, Heat balance, Foliaged season, Defoliated season

京都府相楽郡山城町に位置する山城森林水文試験地北谷流域において, 落葉広葉樹二次林からの蒸発散量を, Thornthwaite-Holzmanモデルにより推定した.モデル定数である影熱の交換効率を示す数値は, 着葉期で 0.12 , 落葉期で0.077と, 着葉期の值は落葉 期の1.5倍に計算された。蒸発散量の上限値は，着葉期には約 $12 \mathrm{MJ} / \mathrm{m}^{2} ・ \mathrm{day} て ゙$ 安定していた。 それに対し落葉期における上限値 は, 11月の約 $6 \mathrm{MJ} / \mathrm{m}^{2}$ •dayから 1 月の約 $2 \mathrm{MJ} / \mathrm{m}^{2}$ ・ dayへと減少し, 4 月の約 $7 \mathrm{MJ} / \mathrm{m}^{2}$ ・ dayへと増加する凹型の季節変化を示し た. 樹種構成や, 林床面蒸発量, 遮断蒸発量を考慮した結果, Thornthwaite-Holzmanモデルによる日蒸発散量の推定精度は, 着葉 期においてはボーエン此法と同程度, 落葉期においてはボーエン比法よりも高いと判断された, 蒸発散量が有効放射量に占める割合 は，1〜 4 月は約 $40 \% ， 5 \sim 11$ 月は約 $60 \%$ あ゙った，この変化は着葉期，落葉期の変化とは約 1 ケ月の遅れがあった．日本の七ノキ 林, スウェーデンのマツ林の季節変化と比較すると, 数值的には同程度であったが, 季節変化には違いがみられた。

キーワード：Thornthwaite-Holzmanモデル，水収支，熱収支，着葉期，落葉期

\footnotetext{
*森林総合研究所関西支所 $\overline{\mathbf{T}} 612$ 京都市伏見区桃山町永井久太郎官有地

Kansai Research Center, Forestry and Forest Products Research Institute, Momoyama, Fushimi, Kyoto, 612, Japan.

**名古屋大学農学部 $7464-01$ 名古屋市千種区不老町

Faculty of Agriculture, Nagoya University, Furo-cho, Chigusa-ku, Nagoya, 464-01, Japan.
} 


\section{I 、はじめに}

関西地域に存在する約 60 万haの落葉広葉樹林は, 落葉樹を中心とした高木層の下に，常緑樹を中心と した低木層が存在するという特街を持つ.そして土 砂流出防備, 里山生暬系の保全, 都市気候の緩和な ど, 環境保全に重要な役割を果たしているといわれ ている.この環境保全機能を評価するためには, 水 文特性を解明することは不可欠である.

関西地域の落葉広葉樹林を対象とした水文特性と しては, 林床面蒸発量 (玉井ら, 1993), 苲散量 (林床面 藎発量を含む) と遮断量の月量(Hattoriら，1994)．3 〜 月切ける蒸発散量と群落コンダクタンス (Tamaiら，1994)が報告されている.しかし，日単位 以下の時間スケールによる点発散量を通年にわたっ て報告した例はない。

環境保全機能の重要な項目である都市気候の緩和 機能や里山生態系の特性を評価するためには, 森林 群落と大気間の相互作用や森林群落の蒸散にともな う生理反応など, より時間スケールの短い現象を多 様な条件下で明らかにする必要がある。これらの研 究を行うためには，より短い時間スケールでの蒸発 散量の通年デー夕は欠かせない.

より短い時間スケールでの蒸発散量の評価には従 来から微気象学的な手法が用いられ, 多くの報告が なされている. 落葉広葉樹林についても池淵ら (1985), Kelliherら (1992), Ogink-Hendriks(1995)な どが報告を行っている. しかしこれらはいずれも着 葉期についてのみであり, 落葉期を含めて報告した 例は極めて稀である.それは, 水蒸気などのスカラー 量のフラックスを長期間に渡って測定する場合には 保守管理上観測が困難な場合(渡辺ら, 1995)や, 濃度 差を高い精度で測定する必要がある(渡辺ら, 1995)の て，本論文で報告する落葉期での落葉広葉樹林のよ うに, 蒸発散量が小さい条件下では推定精度がよく ない場合があるためである。

そこで本論文では，落葉期を含めた期間における 広葉樹林からの日蒸発散量の季節変化を推定するこ とを第一の目的とした，特に冬期におりる広葉樹林 の蒸発散デー夕岋不充分なので, 年間水収支を解明 する上で有意義である.

方法としては, 水蒸気濃度差を精度良く測定する 困難さを避けるため，まず影熱フラックスを推定し， 熱収支式, 短期水収支法と組み合わせることにより，
日蒸発散量を推定した。顕熱フラックスを推定する 方法には乱流変動法が挙げられる。しかしこの方法 を商用電源のない森林流域に長期間に渡って適用す ることは困難である。 またバルク法は, 顕熱フラッ クスの推定に表面温度データを必要とする。しかし 林冠表面のような起伏に富んだ表面での代表性のあ る表面温度測定は難しい。そそれに対し傾度法は 2 高 度間の温度差を用いるので, 代表性のある值の測定 が容易である。そこで傾度法に基づいたThornthwaite-Holtzmanモ $ル ゙$ (Thornthwaiteら, 1939, 以下 $\mathrm{T}$-Hモデルと称する)によって顕熱フラックスを予 測した.

推定された日蒸発散量の信頼性を検討するために， ボーエン比法による推定結果や, 林床面蒸発量, 遮 断蒸発量との比較を行った. また, 落葉期を含めた 熱収支特性も併せて検討した。

\section{II. 理 㖮}

\section{1. 蒸発散量の推定}

森林群落の表面における熱収支式は, 式(1)のよう に表される。

$$
R_{n}-G=H+\lambda E
$$

ここで, $R_{n}$ は純放射量, $G$ は地中熱流量, $H$ は影熱 輸送量, $E$ は蒸発散量, $\lambda$ は蒸発潜熱である。ここで は，森林内の気層および樹体の貯熱変化量は服部 (1985)の試算より無視している.

一方, Thornthwaiteら (1939)は, 大気が中立状態 の場合には式(2)が成り立つとした。

$$
\begin{aligned}
& H=\rho C_{p}\left(u_{2}-u_{1}\right)\left(T D_{1}-T D_{2}\right)(\kappa / B)^{2} \\
& B=\ln \left(z_{2}-d\right) /\left(z_{1}-d\right)
\end{aligned}
$$

ここで, $u$ は風速, $T D$ は気温(乾球温度), $z$ は高度, $d$ は地面修正高, $x$ はカルマン定数, 添え字 1,2 は 観測高度, $\rho$ は大気密度, $C_{p}$ は定圧比熱を示す.

式(2)は次のように変形することができる。

$$
\begin{aligned}
& H=\rho C_{p} A u_{2}\left(T D_{1}-T D_{2}\right) \\
& A=\left(1-u_{1} / u_{2}\right)(\kappa / B)^{2}
\end{aligned}
$$

リチャードソン数の絶対値が十分に小さい場合に は, 風速は式(6)の対数分布になる.

$$
u_{i}=u_{*} x^{-1} \ln \left\{\left(z_{i}-d\right) / z_{0}\right\}
$$

ここで, $u_{*}$ は摩擦速度, $z_{0}$ は粗度長, $d$ は地面修正 高, 添光字 $i$ は観測高度を示し, 本論文では 1 または 2である. 式(6)を式(5)に代入すると， $A$ は $d, z_{0}$,

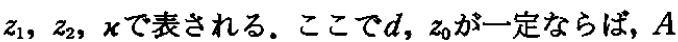
を定数とみなすことができる.したがって $\lambda E$ は式(4) 
を式(1)に代入することにより式(7)で算出される。

$$
\lambda E=R_{n}-G-\rho C_{p} A u_{2}\left(T D_{1}-T D_{2}\right)
$$

$A$ 值の算定には, 式(7)を変形した式(8)と, Suzuki (1980)の提案した短期水収支法によって Hattoriら (1994) が推定した本流域における月別蒸発散量の推 定值 $\left(E_{s b}\right)$ を用いた。

$$
A=\left(R_{n}-G-\lambda E_{s b}\right) / \rho C_{p} u_{2}\left(T D_{1}-T D_{2}\right)
$$

ここで用いた方法は，短期水収支法で得られた蒸 発散量を熱収支法に取り込むことより，短期水収支 法による長期間にわたる平均の蒸発散量を, 短期間 の蒸発散量に再配分する試みであり, 流域内の地形 や林分条件の不均一性の影響を小さくすることがで きると考えられる。

2. ボーエン比法と短期水収支法

式(7)による蒸発散量を, ボーエン比法と短期水収 支法による推定值と比較した.

ボーエン比法は，式(9)，(10)，(11)で表される.

$$
\begin{aligned}
& \lambda E_{b}=\left(R_{n}-G\right) /(1+\beta) \\
& \beta=\gamma\left(T D_{1}-T D_{2}\right) / C \\
& C=(\delta+\gamma)\left(T W_{1}-T W_{2}\right)-\gamma\left(T D_{1}-T D_{2}\right)(11)
\end{aligned}
$$

ここで, $\lambda E_{b}$ は, ボーエン比法による $\lambda E$ の計算 値, $\left(T W_{1}-T W_{2}\right)$ は湿球温度差, $\delta$ は水蒸気圧曲線の 勾配, $y$ 沽湿計定数である。

流域における水収支式は, 式(12)のように表される.

$$
E=P-D \pm \Delta S
$$

ここで, $P$ は降水量, $D$ は流出量, $\Delta S$ は土壤貯留量 の増隇量である.Suzuki(1980)は,ハイドログラフか

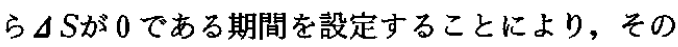
期間中の $E$ を推定する短期水収支法を提案している. 本論文におけるEの計算は, このSuzuki(1980)の方 法に準拠した.

\section{III. 試験流域及び測定方法}

\section{1. 流域の概要}

観測を行った森林流域は, 京都府相楽郡山城町に 位置する山城森林水文試験地北谷流域 (北緯 $34^{\circ} 47^{\prime}$ 東 経13551')で(図一1)，流域面積は約1.6haである。コ ナラ,ネジキなどの落葉広葉樹が優先しているが, ソヨゴ, ヒサカキなどの常緑樹も混在している. 胸 高断面積合計注落葉広葉樹 $13.3 \mathrm{~m}^{2} / \mathrm{ha}$, 常緑樹 6.3 $\mathrm{m}^{2} / \mathrm{ha}$ と, 落葉広葉樹が約 3 分の 2 を占めている.そ のため, 着葉期と落葉期とでは, キャノピーの構造 が大きく異なる。落葉広葉樹は，4 月下旬から 5 月 上旬にかけて開葉し，10月下旬から11月上旬にかけ

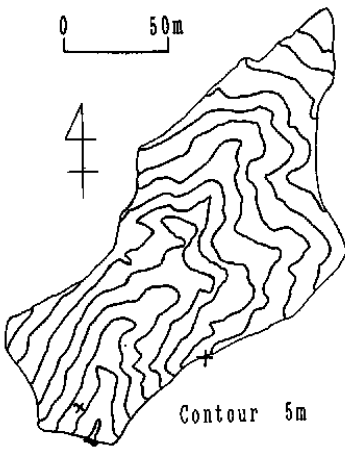

図一 1 山城森林水文試験地北谷流域の地形図と観 測施設の纪置

$-:$ 量水堰 $+:$ 森林微気象観測鉄塔 $\times:$ 雨量計

て落葉する. 林冠の開空度は, 林床から魚眼レンズ でキャノピーの写真を撮影して求めた結果, 着葉期

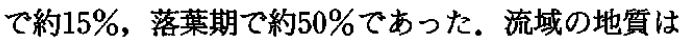
風化花こう岩で, 土埣は砂質で未熟土的であり, 土 層は全般的に薄い.

\section{2 、観測，解析方法}

图一1に示した尾根上に観測鉄塔を設置し, 森林 微気象の観測を行った. 観測鉄塔周辺の平均樹木高

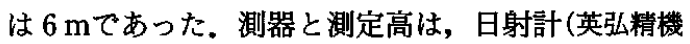
製 MS-42)が $12 \mathrm{~m}$, 放射収支計(英弘精機製 $\mathrm{CN}-11$ ) が10m, 通風筒付乾湿球温度計(英弘精機製 $\mathrm{MH}-$ $020)$ が $8,10 \mathrm{~m}, 3$ 杯式風速計(中浅湘器製 $\mathrm{A} 701$ ) が $8,10 \mathrm{~m} ゙$ あった。乾球温度差 $\left(T D_{1}-T D_{2}\right)$, 湿球温 度差 $\left(T W_{1}-T W_{2}\right)$ は, 高さ $10 \mathrm{~m}$ と $8 \mathrm{~m}$ の間の温度差を 測定した. 地中熱流板 (英弘精機製 $\mathrm{CN}-81$ ) $0.05 \mathrm{~m}$ の深さに埋設した.すべての測定項目は30秒間隔で スキャンし, $\left(T D_{1}-T D_{2}\right),\left(T W_{1}-T W_{2}\right)$ と $T D$, $T W$ は0分おきに 5 分間のみの測定值を, 他の項目 は全ての測定值を，それぞれ30分間隔で平均して データロガー(英弘精機製 MP-090, NEC製PC-98 LT)に記録した。

降水量は, 露場に設置した転倒マス式雨量計(池田 計器製 SKI-1)で, 流出量は $90^{\circ}$ ノッチを用いた量水 堰堤の水位をフロート式水位計(池田訫器製 ADR105WP)によって測定した。

式(7)，(8)，(9)の計算に用いたデー夕は，1992年 1 〜12月の日中の值である. 降雨中のデータも含めて 計算を行った。式(7)，(9)の計算は30分間隔で行い, 算出された值を日量に積算した。 また，夜間の蒸発 
散量は極めて少ないと予想されるので，日中につい てのみ計算した.リチャードソン数の絶対值が 0.05 を越えた場合の $\lambda E, u_{2}\left(T D_{1}-T D_{2}\right)$ は, 前後の時間 帯での平均値を代入した。 なお，着葉期は $4 \sim 10$ 月， 落葉期は $11 〜 3$ 月とした.

\section{IV. 結果と考察}

リチャードソン数の絶対值が 0.05 を越えた時間は 多くなく, 解析への影響はないものと思われた。

\section{Aの同定}

式(8)による計算結果を図一 2 に示す. $A$ 值は, ばら つきがあるものの着葉期の方が落葉期より大きい. $A$ 値は顕熱の交換効率に関する定数であることから, 葉量への依存性が高く，そのため着葉期と落葉期て 傾向が異なるものと思われる，バルク係数は，葉面 積密度が中程度で最大となり, 非常に粗な場合と非 常に密な場合には交換効率が悪くなる(渡辺, 1994) など, 森林群落における交換効率と葉量の間には密 接な関係がある.

北谷流域の主要構成樹種であるコナラは, 隅田 (1993)によれば着葉期間の初期から終期まで葉を保 持し続け, 最後に一斉に葉を落とすと報告している. また, 主要構成樹種のひとつであるリョウブのリ ターフォールの季節変化パターンもコナラと同様, 終期に集中している(隅田, 1993)。このことや, 林内 相対日射率が着葉期間は約 $15 \%$, 落葉期は約 $40 \%$ と 安定している(玉井ら，1994)ことから，本流域の森林 では着葉期，落葉期における葉量はそれぞれの期間 においてほほ一定に推移しているものと思われる. したがって, $\lambda E$ を算出するに際して, $A$ 値は着葉期 と落葉期のそれぞれにおける平均値を用いることと した. $A$ 平均値は着葉期で 0.12 , 落葉期で 0.077 と 計算され, 着葉期における值は落葉期の 1.5 倍となっ た.

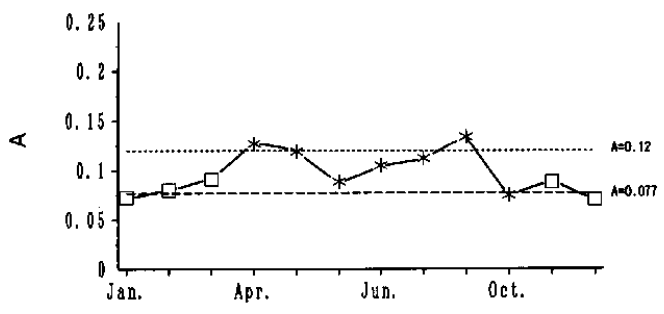

図一 $2 A$ 值 $(E q .(8))$ の季節変化 (1992年の場合)

*: 着葉期 $\square$ : 落葉期
なお, 玉井ら (1995) は, 本流域を対象に基準高度 $z_{2}$ に対しての顕熱バルク係数を, 遮断蒸発時の空気力 学的抵抗と風速の関係から0.077と報告している.顕 熱バルク係数は大気中の 1 高度と蒸発面の間におけ る顕熱の交換効率を表すのに対し， $A$ 值は接地気層 中の 2 高度間における影熱の交換効率を表す，Aは この年間を通してのバルク係数值の, 着葉期で約 1.5 倍, 落葉期で同程度でった。

\section{2. 蒸発敬量の季節変化}

着葉期, 落葉期における $A$ の值をそれそれ0.12, 0.077 として,式(7)から蒸発散量を計算した結果を図 - 3 に示す. 着葉期の蒸発散量の上限値は $12 \mathrm{MJ} /$

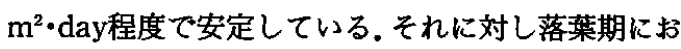
ける蒝発散量の上限值は, 11月の約 $6 \mathrm{MJ} / \mathrm{m}^{2} \cdot$ dayか ら 1 月の約 $2 \mathrm{MJ} / \mathrm{m}^{2} \cdot$ dayへと減少し, 4 月の約 7 $\mathrm{MJ} / \mathrm{m}^{2}$ ・ dayへと増加する凹型の季節変化を示した。

$\lambda E$ が負值となる日が 2 日認められる.これらの日

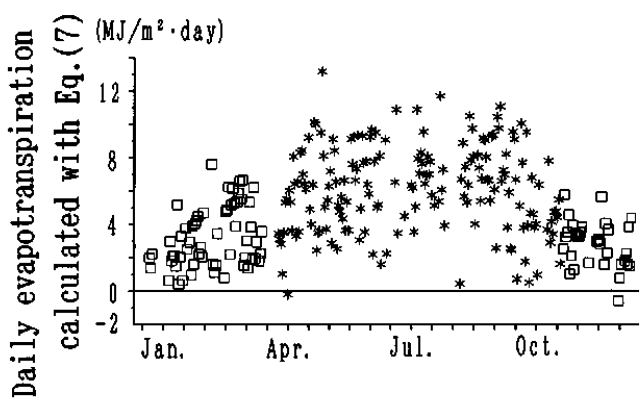

図一３日蒸発散量計算侹の季節变化 (1992年の場合)

*: 着葉期 $\square$ : 落葉期

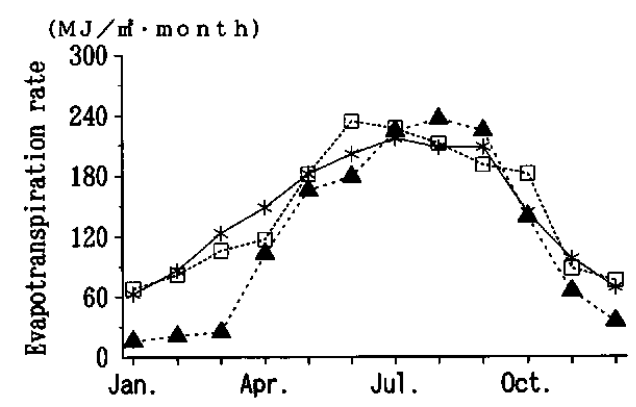

图一4蒸発散量計算值の比較(1992年の場合)

$$
\begin{aligned}
& *: \mathrm{T}-\mathrm{H} \text { 法 }(\lambda E), \text { Eq. (7) } \\
& \mathbf{\Delta}: \text { ボーエン比法 }\left(\lambda E_{b}\right), \text { Eq. (9) } \\
& \square: \text { 短期水収支法 }(E), \text { Eq. (12) }
\end{aligned}
$$

(Hattoriら (1994) から引用) 
は，いずれも終日に渡って純放射量の值が小さく， 蒸発散が活発でなかった。 また負值の絶対值は小さ いので，期間全体にわたっての影響は小さいと考え る.したがって今後の考察は, これらの值も含めて 行う.

図一 4 に式(7)，(9)による $\lambda E, \lambda E_{b}$ の計算値と短期 水収支法による推定値 $(E)$ の月別值を示す。まず, $\lambda E$ と $\lambda E_{b}$ について比較する. 1992年 $1 \sim 3$ 月,

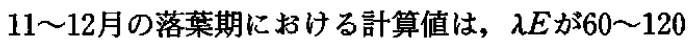
$\mathrm{MJ} / \mathrm{m}^{2}$ ・月, $\lambda E_{b}$ が20 $60 \mathrm{MJ} / \mathrm{m}^{2}$ ・月と, $\lambda E_{b}$ の方が かなり小さな值となった。 $\lambda E_{b}$ は92年の気象観測值 に基づいた計算值であるのに対し, $\lambda E$ は $A$ の同定に 短期水収支法による蒸発散量の計算值を用いた。こ の值は複数年に渡っての平均値であり，根拠となる 観測期間が異なるため, 両者の違いは年変動に起因 するとも考えられる。しかし1992年の冬期は, 気温 は平年值よりも高めであるが, 降水量と日照時間は ほほ平年なみであった。さらに観測年は異なるが, 玉井ら (1994) は落葉期における北谷流域の林床面蒸 発量を約 $0.4 \sim 0.6 \mathrm{~mm} / \mathrm{day}$ (約 $30 \sim 40 \mathrm{MJ} / \mathrm{m}^{2}$ ・月) と見 積もっている. 北谷流域には, 胸高断面積合計にし て約 $6.3 \mathrm{~m}^{2} / \mathrm{ha}$ の常緑樹が低木を中心にして存在し ている.これは総断面積合計の約 3 分の 1 を占める. そのため, 北谷流域では落葉期でもある程度の蒸散 量が見込まれる。また, Hattoriら (1994)は, 北谷流 域の落葉期においても約 $10 \mathrm{~mm} /$ 月程度の遮断蒸発量 を報告している。これらの点を考慮すると, $\lambda E_{b}$ の值 はかなり小さい、したがって落葉期における蒸発散 量の推定值としては， $\mathrm{T}-\mathrm{H}$ 法による値の方が妥当 であり, $\lambda E_{b}$ が過少評価されていると判断される。そ の原因としては, 湿球温度差の測定誤差が考えられ る. 着葉期の 7 月には $0.4^{\circ} \mathrm{C} / 2 \mathrm{~m}$ の温度差を日中に 示すのに対し, 落葉期では $0.1^{\circ} \mathrm{C} / 2 \mathrm{~m}$ 上回るのは 稀であった。このため, 落葉期における測定値に占 める測定誤差の割合は高くなり，落葉期における $\lambda E_{b}$ が過少に計算されるものと考えられる。

$4 \sim 10$ 月の着葉期には, $\lambda E$ は約 $210 \mathrm{MJ} / \mathrm{m}^{2} \cdot$ 月, $\lambda E_{b}$ は2 $230 \mathrm{MJ} / \mathrm{m}^{2}$ ・月と同程度の值を示しおり, $\lambda E$, $\lambda E_{b}$ ともに妥当な季節変化を示しているものと判断 される.ちなみにSuzuki (1980) は, 桐生試験地におけ る 7,8 月の蒸発散量を約 $96 \mathrm{~mm} /$ 月 (約 $230 \mathrm{MJ} / \mathrm{m}^{2}$ •月) と報告している.

以上より, 式(7)による計算精度は着葉期において は式(9)と同程度, 落葉期においては式(9)よりも高い と判断された.

\section{3、日旦の比較}

$\lambda E$ と $\lambda E_{b}$ の日量を着葉期について比較すると（図 -5 ), 両者の間には正の相関が䜑められる. $\lambda E$ の值 が $6 \mathrm{MJ} / \mathrm{m}^{2}$ ・day以上の場合と以下の場合に分ける と, $6 \mathrm{MJ} / \mathrm{m}^{2} \cdot$ day以下の場合の方が, $\lambda E_{b}$ の値が過 少である傾向がある、これは前項でも検討したよう に, 蒸発散量が少ない場合には $\lambda E_{b}$ は過少評価にな る傾向にあることを反映しているためと思われる。

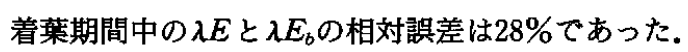
また, 両者の直線回㷌式は, 回㷌定数を 0 と固定す

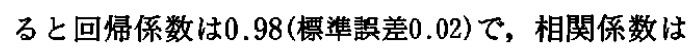
0.69であった.このことから, 着葉期における日蒸 発散量に関して, 式(7)は式(9)と同程度の精度である と判断された。落葉期(図一5)については, 前項での 検討からもわかるように，ほとんどすべての日につ

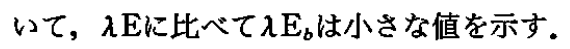

落葉期における $\lambda E$ の日量を直接検証することは できない.しかし,着葉期においては T-H法とボー エン比法とは同程度の精度であること, 落葉期でも 約 $10 \mathrm{~mm} /$ 月程度の遮断蒸発があること, 樹種構成, 落 葉期における林床面蒸発量の推定值 (玉井ら, 1994)な どから, 落葉期における $\mathrm{T}-\mathrm{H}$ 法による $\lambda E$ の日量も

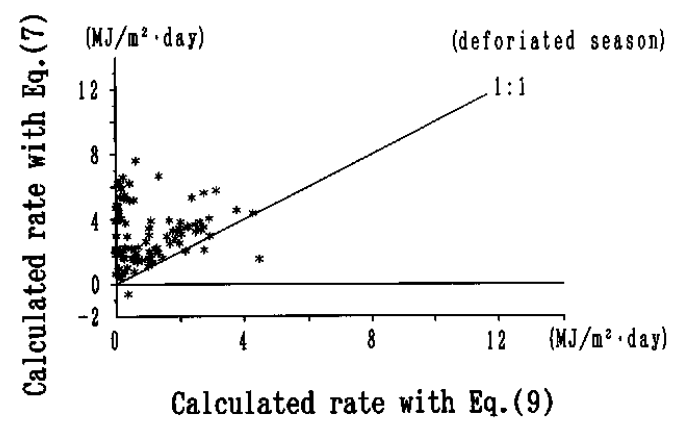

(a) 落葉期

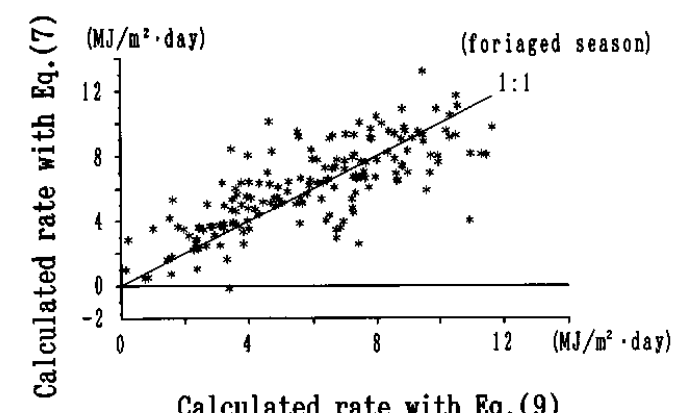

Calculated rate with Eq. (9)

(b) 着葉期

図一 5 日蒸発散旦計算値の比較(1992年の場合) 
着葉期と同様に妥当な值であると考えられる.この 点については, 乱流変動法による顕熱フラックスの 測定を行うなどの検証が必要であろう。

\section{4. 流城の熱収支特性}

图一6に有効放射量 $\left(R_{n}-G\right)$ の観測値と $\lambda E$ の計

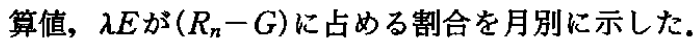
$\lambda E$ が $\left(R_{n}-G\right)$ に占める割合は，おおよその傾向と して $1 \sim 4$ 月は約 $40 \% ， 6 〜 11$ 月の平均で約 $60 \% て ゙$ あった。この変化は着葉期,落葉期の期間とは約 1 ヶ 月の遅れがあった。図一6によると $\left(R_{n}-G\right)$ は 3 月 から 4 月に急増したのに対し， $\lambda E$ はそれに追随して 増加しない.これは，4月における落葉樹は開葉の 途中であるため, 蒸発散がそれほど盛んではないた

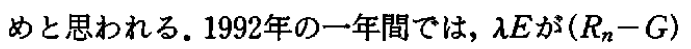
の55\%を占めた. Hattori(1987)によると, ヒノキ林 における 4 〜0月の純放射量に占める地中貯熱量は $2.4 \%$ どくわずかである一方, 蒸発散量の占める割 合は40〜50\%であった.またLindroth(1985)は，ス ウェーデンのマツ林を対象に 5 10月の熱収支を月
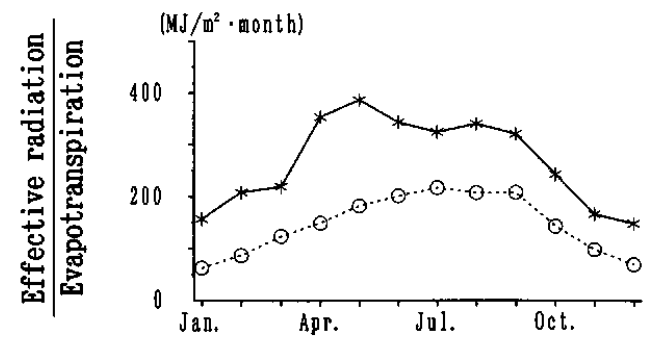

（a）有効放射量, 蒸発散量の季節変化

* : 有効放射量 $\left(R_{n}-G\right)$

$O:$ 蒸発散量 $(\lambda E)$

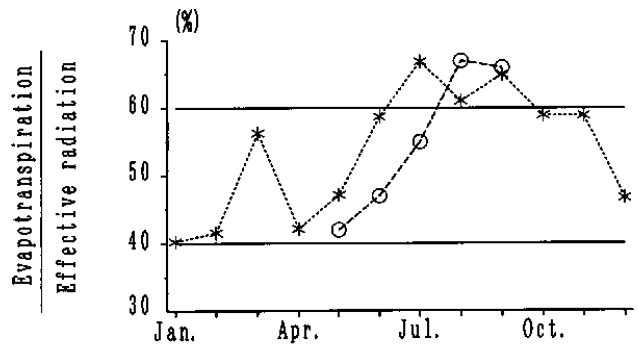

(b) 蒸発散量が有効放射量に占める割合 $\left(\lambda E /\left(R_{n}-G\right)\right)$ の季節変化

$*$ : 山城水文試験地

$\mathrm{O}:$ Jadraas

(Lindroth (1985) から引用した数値から算出)

図一6 第収支の季節変化
別に報告している.それらの数值から有効放射量に 占める蒸発散量の占める割合を計算すると約 42〜 67\%となった(图一6). 数值の範囲としては, 同 程度であるが，季節変化には若干の違いがみられた。 つまり, 約 $40 \%$ の数値を示す期間が, 北谷流域では $1 \sim 4$ 月であるのに対し, Hattori(1987)の場合は 4, 6〜8 月であった. またLindroth(1985) が報告し た春から夏にかけての変化は, 北谷流域に比べると 1 ケ月遅れであった。これは日本とスウェーデンの 気候の違いによると推定される.

\section{V.おわクに}

Thornswaite-Holzmanモデルにより顕熱量を推 定し, 短期水収支法, 熱収支式と組み合わせること により, 落葉広葉樹林からの蔒発散量を算出した。 交換効率を表す変数 $A$ は, 葉量に依存し, 着葉期で

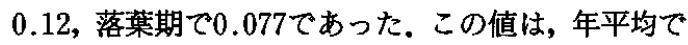
の顕熱バルク係数の1.0〜1.5倍であった.

ボーエン比法による推定値や林床面蒸発量, 遮断 蒸発量と比較, 検証を行った。その結果, ボーエン 比法による推定值は落葉期に過少に推定されるのに 対し， $\mathrm{T}-\mathrm{H}$ 法による計算值は着葉期・落葉期を通 じて妥当な季節変化が得られた，着葉期における $\mathrm{T}-\mathrm{H}$ 法による日蒸発散量計算値を, ボーエン比法 による推定值と比較した結果, 相対誤差 $28 \%$, 相関 係数 0.69 と良好な結果が得られた.このことから $\mathrm{T}-\mathrm{H}$ 法は, 着葉期における日蒸発散量の推定に関 しては, ボーエン比法と同程度の精度をもつものと 判断された. 落葉期の日蒸発散量についても, T一 H法による推定精度は高いと推測されるが, 今後の 検証を必要とする。

$\mathrm{T}$ 一 H法による日蒸発散量推定值は，ばらつきは 大きいものの着葉期の方が大きな值を示す傾向が あった。落葉期で $6 \mathrm{MJ} / \mathrm{m}^{2} \cdot$ day程度, 着葉期て12 $\mathrm{MJ} / \mathrm{m}^{2} \cdot$ day程度を最大值とした. 有効放射量と比較 した場合, 年間で有効放射量の約 $55 \%$ が蒸発散に消 費された. 月別では， 1〜 4 月が約 $40 \% ， 6 \sim 11$ 月 が約 $60 \%$ でった．この変化は, 着葉期, 落葉期の 期間とは約 1 ヶ月の進れが認められた。

䀣辞：森林総合研究所関西支所造林研究室長の清 野嘉之博士には, 有益なご助言をいただきました。 ここに謝意を表します。 


\section{引用文献}

服部重昭(1985)：蒸発散量推定式の誘導過程の解説 と林分の適用におりる問題点, 林試研報, $332, \mathrm{pp}$. 139-165

Hattori, S. (1987) : Seasonal variation of radiation and energy balances in a hinoki stand, In: Proceedings of the Vancouver Symposium: IAHS-AISH publ. no. 167, pp. 349-355

Hattori, S. and Tamai, K. (1994) : Characteristics of water balance in a deciduous secondary forest, In: Proceedings of the International Symposium on Forest Hydrology. pp. 577-584 池淵周一, 沢井 康 (1985)：林地蒸発散量の長期間 にわたる時系列推定, 京都大学防災研究所年報,

28B-2, pp. 157-177

Kelliher, F.M., Köstner, B.M.M., Schulze, E. D., Hollinger, D.Y., Byers, J.N., Hunt, J. E., McSeveny, T.M., Meserth, R. and Weir, P.L. (1992) : Evaporation, xylem sap flow, and tree transpiration in a New Zealand broad-leaved forest, Agric. For. Meteorol., 62, pp. 53-73

Lindroth, A. (1985) : Seasonal and diunal variation of energy budget components in coniferous forests, J. Hydrol., 82, pp. 1-15

Ogink-Hendriks, M.J. (1995) : Modelling surface conductance and transpiration of an oak forest in The Netherlands, Agric. and For.
Meteorol., 74, pp. 99-118

隅田明洋 (1993)：二次林における階層構造の解析, 名古屋大学演習林報告, 12, pp. 31-145

Suzuki, M. (1980) : Evapotranspiration from a small catchment in hilly mountains (I). Seasonal variations in evapotranspiration, rainfall interception and transpiration, J. Japan For. Soc., 62, pp. 46-53

玉井幸治, 服部重昭(1994)：落葉広葉樹林における 林床面蒸発のモデル化と流域への適用, 日林誌,

76, pp. 233-241

Tamai, K. and Hattori, S. (1994): Characteristic of canopy conductance of a deciduous broad -leaved forest, In: Proceedings of the International Symposium on Forest Hydrology. pp. 147-154

玉井幸治, 服部重昭(1995)：落葉広葉樹林における 「蒸発効率」の特性, 水水学会1995年研究発表会 要旨集, pp. 28-29

Thornthwaite, C.W., and Holtzman, B. (1939): The determination of evaporation from land and water surface, Mon. Weather Rev., 67, pp. 4-11

渡辺 力 (1994): 植物と大気, (近藤純正編著: 水環 境の気象学, pp348, 朝倉書店, 東京), pp. 208-234 渡辺 力 (1995) : バンドパス・渦相関法による森林 上のスカラーフラックス. 日本気象学会1995年度 秋季大会講演予稿集, pp. 48

(1996年 2 月 8 日受付，1996年 5 月 10 日受理) 